821.163.41.09-94 Данило II, српски архиепископ

271.222(497.11)-36:929 Сава, свети

https://doi.org/10.18485/msc_pred.2019.8.ch1

\author{
Љиљана ЈУХАС-ГЕОРГИЕВСКА \\ Универзитет у Београду \\ Филолошки факултет
}

\title{
ЛИК СВЕТОГ САВЕ У ДАНИЛОВОМ ЖИТИЈУ АРХИЕПИСКОПА АРСЕНИЈА
}

1.

У корпусу дела која је саставио архиепископ Данило Други, житије посвећено архиепископу Арсенију I има запажено место. ${ }^{1}$ Настало је, веpyje ce, око 1330. године, у Пећи, док су текли радови на подизању цркве Богородице Одигитрије (њен ктитор је Данило). У склопу овог храма, који је постављен јужно од раније изграђене цркве Св. Апостола, изграђен је параклис Св. Арсенија. Између 1330. и 1337, по Даниловој жељи, на зидовима тога параклиса насликан је циклус фресака (четири композиције); ту $\mathrm{je}$, у сажетом виду, представљен живот овог црквеног поглавара. Сачуване су две композиције (устоличење Арсенија за архиепископа и заупокојена литургија над мртвим телом архиепископа Арсенија); оне су насликане на јужном зиду параклиса. Друге две (Св. Сава производи Арсенија за ђакона; Свети Сава уздиже Арсенија у чин презвитера), урађене на северном зиду, временом су нестале. Њихова тематика позната је захваљујући томе што су натписи сачувани а понегде и горњи део извесних фигура. ${ }^{2}$ Житије и служба посвећена Св. Арсенију по свој прилици настали су пре сликарског програма. Њега је морао осмислити Данило Други, па је занимљиво питање односа између текста и фресака. Војислав Ј. Ђурић,

\footnotetext{
${ }^{1}$ Архиепископ Данило Други написао је житије краљева Драгутина и Милутина и житије краљице Јелене. Саставио је и житија архиепископа Јоаникија и Јевстатија. Од њега потичу и Служба архиепископу Арсенију и Служба архиепископу Јевстатију. Данилова намера била је да своја житија окупи у зборнику.

${ }^{2}$ Војислав Ј. Ђурић, Историјске композищије у српском сликарству средњега века и ғихове књижевне паралеле, Зборник радова Византолошког института 11, 1968, 99-127.
} 
проучавајући сачуване фреске, дошао је до закључка да се сликари нису дословно држали текста, ни током представљања појединости из Арсенијевог живота „ни при утврђивању редакције циклуса као целине”. 3 За тему којом се бавимо, значајна је опсервација овог историчара да је Данило избором сцена повезао Арсенијев живот са животом Светог Саве, истичући притом Савину улогу у Арсенијевом уздизању до архиепископског чина. Релевантно је и његово мишљење да се тежило успостављању модела за писање и за сликање, када је реч о црквеном поглавару. Говорећи о Арсенијевом сликаном житију, В. Ј. Ђурић сугерише да се оно у програмском и формалном смислу приближило идеалној скраћеној верзији циклуса угледних хришћанских архијереја, пре свега циклусу Св. Николе. ${ }^{4}$

2 .

До Даниловог времена Арсеније није добио опширнији животопис. Постојало је само пролошко житије овог светитеља. Сматра се да га је саставио неки монах у Пећи, у време архиепископа Саве Другог (управљао Српском црквом између 1264. и 1271). Извесни моменти из Арсенијевог живота (освећење за архиепископа, учешће у преносу моштију Св. Саве из Трнова у Србију), унеколико су представљени код Савиних биографа Доментијана и Теодосија. ${ }^{5}$

Арсеније I Сремац на челу Српске цркве налазио се пуних тридесет година, од 1233. до 1263. Њега је Св. Сава одабрао за свога наследника на трону српске архиепископије. Арсеније је мудро и успешно водио цркву пуних тридесет година. Након татарске најезде кроз Европу, када је Жича била опустошена, он је на жичком метоху у Руговској клисури, у близини Пећи, саградио цркву Светих Апостола. Ту је, око 1253. године, преместио седиште српске архиепископије. Када је тешко оболео 1263, напустио је свој положај архиепископа. Наследио га је Сава II, четврти син краља Стефана Првовенчаног. Арсеније је умро у Чрнчи, октобра 1266, а сахрањен је у храму Светих Апостола у Пећи. ${ }^{6}$ Данас се његове мошти налазе у манастиру Ждребаонику у близини Даниловграда у Црној Гори. ${ }^{7}$

\footnotetext{
${ }^{3}$ Исто, 100.

${ }^{4}$ Исто, 100-102.

${ }_{5}^{5}$ Доментијаново Житије св. Саве довршено је 1242/43. или 1253/54, а Теодосијево истоимено дело крајем XIII или на самом почетку XIV века.

${ }^{6}$ Протојереј др Радомир Поповић, Кратак преглед српске иркве кроз историју, Београд, 2000, 87-88.

${ }^{7}$ Арсенијеве мошти су се у Пећи налазиле до 1724 . Потом су сељене из једног манастира у други. Оне се од 1920. налазе у манастиру Ждребаонику, а ту су донете из манастира Косијерево.
} 
3.

Данило Други је са великим поштовањем и љубављу писао о архиепископу Арсенију, другом по реду српском архиепископу, кога је на трон поставио Свети Сава. ${ }^{8}$ Ослонио се на манастирску традицију и, како сам истиче, на усмене изворе. Каже да су му Арсенијев живот (у првом реду његов велики подвиг) описали неки богобојажљиви мужеви, који су слушали о овом Преосвећеном. Постојеће пролошко житије могло је дати одређене смернице у конципирању лика, али није битније утицало на Данилов рад. Много је значајније његово ослањање на Доментијаново Житије Светог Саве. Овај писац, представљајући Арсенијев избор за архиепископа, истиче његове карактеристике и врлине: богоуман и побожсан, подобан богооиу Давиду, кротак и смеран по срцу воље Божје. Наглашава и одређену Арсенијеву блискост са Светим Савом. Попут Саве, био је и он изабран још из материне утробе и назнаменан на светињу и на спасење многима. Доментијан представља и сабор на коме је Сава осветио Арсенија за архиепископа. Потом говори о томе како је Сава предао Арсенију Богом предану му паству свога отачаства, утврдивши га добро у чину преосвештенства; благословио га је сваким благословом и посадио га је на свој престо. ${ }^{9}$ О Арсенију Доментијан говори и поводом преноса Савиних моштију из Трнова у Србију. Према Доментијановом казивању, он је са свештенством и монаштвом, на српској граници, радосно дочекао Савине мошти. У завршном сегменту житија, који је оформљен као запис, такође се помиње Арсеније. Говорећи о времену довршавања дела (саопштена је година), писац наводи имена актуелних владара (грчког и српског). Затим бележи име српског архиепископа (Арсеније), уз констатацију да придржава престо преосвећеног кир Саве. Наглашава да је богоносни отац и други архиепископ српски. Теодосије, који иде за Доментијаном, такође приповеда о Арсенијевом избору за архиепископа и његовом учешћу у преносу моштију Светог Саве. ${ }^{10}$ Овај писац Арсенију приписује и иницијативу за пренос моштију. Код њега се сусреће и податак да је Сава, тешко

\footnotetext{
${ }^{8}$ Данило Други, Живот архиепископа Арсенија, у: Данило Други, Животи краљева u архиепископа српских. Службе. Приредили Г. Мак Данијел и Д. Петровић, Просвета-СКЗ, Београд, 1988, 153-179. (У даљем тексту за ово издање користимо скраћеницу: Дан ЖАр).

${ }^{9}$ Доментијан, Житије Светога Саве. Предговор, превод дела и коментари Љ. ЈухасГеоргиевска. Издање на српскословенском Т. Јовановић, СКЗ, Београд, 2001 (упоредно се дају српскословенски текст и превод на савремени језик). (Надаље за ово издање користимо скраћеницу: ДомЖСа).

${ }^{10}$ Теодосије, Житије Светог Саве, у: Теодосије, Житија. Приредио Д. Богдановић. Данашња језичка редакција Л. Мирковић и Д. Богдановић, Просвета-СКЗ, Београд, 1988, $101-261$.
} 
болестан у Трнову, у писму даровао мир и благослов Арсенију (послао је благослов и тадашњем српском краљу Владиславу).

Расположиву грађу Данило је умешно користио; лик другог српског архиепископа умногоме је оживотворио захваљујући својој снажној стваралачкој имагинацији.

Житије црквеног поглавара као житијни тип оформљено је заслугом Доментијана а потом и Теодосија. Успостављена су општа места и принципи у карактеризацији јунака. Данило је, приступајући писању свога житија, већ имао одређени модел, који је могао у потпуности или пак делимично следити. На глобалном плану (редослед мотива), писац прати стандардну житијну схему. Измене се примећују на плану просторне организације текста; поједини мотиви шире су утемељени и фаворизовани (Арсенијево подвизавање и напредовање, освећење за архиепископа, посмртна чуда), док су неки други овлашно представљени (махом је реч о почетним мотивима). Текст житија разлаже се на 17 целина (поглавља). Почиње похвалом јунаку а довршава се приказом његових посмртних чуда. На самом крају долази белешка о дужини Арсенијевог управљања Српском црквом. Назначен је и датум његове смрти (28. октобар).

У Житију се у значајној мери изграђује лик Светог Саве. Првог српског архиепископа писац не представља само у својству јунаковог духовног оца и руководиоца у подвигу, што би се очекивало, већ настоји да истакне његов целокупни значај за српску државу и цркву. На његову тежњу да што потпуније и целовитије изгради Савин лик, указује и чињеница да он говори и о догађајима који нису у непосредној вези са главним јунаком (представља Савин одлазак у Приморје, где очекује брод којим ће путовати у Свету Земљу, његов сусрет са тамошњим народом, укрцавање и полазак на пут, итд.). Свестан чињенице да би указивање на Савине подвиге током ходочашћа битно нарушило композициону структуру, он упућује читаоце/слушаоце да су даљи трудови Савини и његови подвизи представљени засебно у писаним књигама његовог богоугодног живота (заправо код Доментијана и Теодосија). ${ }^{11}$ И квантитативни показатељи (о Сави се говори у шест од укупно седамнаест поглавља), указују да је Савин лик у структури дела необично значајан. Свети Сава је на страницама Арсенијевог житија присутан и на други начин. Данило свога јунака промишља као другог Светог Саву; оваква интенција запажа се од самог почетка текста. У складу са оваквом поставком, писац настоји да код Арсенија истакне особине и својства који га могу приближити Сави. У ту сврху користи исказне формулације, квалификативе, симболику и др., коју користи Савин биограф Доментијан, глорификујући свога јунака. Како смо указали, Доментијан је, приповедајући о Арсенијевом избору за

\footnotetext{
${ }^{11}$ ДанЖАр, 165.
} 
архиепископа, отворио могућност за успостављање паралеле: Арсеније - Свети Сава. У другом делу Житија Светог Арсенија, Свети Сава је присутан посредно, симболички. Живо је присутан у памћењу (кроз добре успомене и мудре поуке). Као Свети, својим молитвама, које Бог прима, он помаже отачаству (све чини на добро). Архиепископ Арсеније, заснивајући на темељима Савиног програма своје деловање, актуелизује га и одржава живом Савину традицију и величанствену успомену на њега.

Приповедање у житију се зачиње истицањем чињенице да је после Светог Саве постао други архиепископ на његовом престолу, Свети Арсеније. ${ }^{12}$ Одмах се наглашава да предстоји „многа беседа”, због многобројних чудеса Арсенијевог живота. За помоћ при састављању житија и инспирацију, Данило се обраћа најпре Богу а потом и самом Арсенију. Молитва Богу је значајна јер је у њу инкорпорирана похвала Арсенију. ${ }^{13}$ Полази се од чињенице да је Арсеније постао угодан светитељ Трисијанога божаства. Затим се истиче да краси поднебесно еванђелским учењем а да саборе правоверних освећује Духом Светим. Данило назначава да је у овом блаженом отпочинула савршена истина, сам Христос и да се назвао обитељу једносушне Тројице, итд. Наглашавајући јунакове вредности и заслуге, Данило настоји да укаже на потребу за састављањем његовог животописа. Похвала, осим што представља неку врсту биографије у малом, важна је и по томе што омогућава увид у суштинску поставку Данилову; он тежи да Арсенијев лик изгради по угледу на Савин. Писац тако констатује да је Арсеније још од младости своје означен Духом Светим. Овде се запажа утицај Доментијана; он додуше истиче да је Сава још у материној утроби назнаменан самим Господом. ${ }^{14}$ Данило говори о назнаменању које се догодило у Арсенијевој младости. Без обзира на различитости, код оба писца истакнуто је једно исто: чињеница Божје изабраности. Овај, али и неки други примери преузимања, указују да Данило не опонаша слепо свој извор већ да је његов приступ креативан. Даље, Данило назначава постојање дара прозорљивости код Арсенија: „кроз Њега [тј. Светог Духа] унапред предвиде будућа блага у вечном награђивању"15. Истоветан дар поседовао је и Свети Сава; он је, нпр. Духом Светим унапред видео предстојећу благодат намењену Немањи. О томе говори Доментијан. ${ }^{16}$ Својеврсно поређење са Св. Савом запажа се и када је реч о великој побожности Арсенијевој (имао је уздање у Бога; к Њему је прибегао силним умом и веледушним разумом), о његовом духовном деловању (учитељ побожности) и о чудесним

\footnotetext{
${ }^{12}$ ДанЖАр, 153.

${ }^{13}$ Исто, 153.

${ }^{14}$ ДомЖСа, 377.

${ }_{15}^{15}$ ДанЖАр, 152.

${ }^{16}$ ДомЖСа, 43.
} 
моћима (чинио је дивна чудеса милошћу љубитеља својега Христа). ${ }^{17} \mathrm{O}$ истоветним Савиним карактеристикама и особинама говори Доментијан на више места у своме житију. У саставу похвале код Данила је и библијска паралела: Арсеније-библијски праведници Авраам, Исак и Јаков (и он је, попут њих, наследио истинити живот). ${ }^{18}$ Паралела Свети Сава - Авраам, Исак и Јаков сусреће се у Доментијановом делу. Веза се успоставља на основу чињенице да су и Сава и библијски праведници удостојени да виде превелику светлост (заправо да буду у рају). ${ }^{19}$ Данило не само да је у Доментијановом тексту нашао подстицај да реализује паралелу, већ се очигледно угледао на овога писца, преузимајући његово стилско решење (користи полисиндет) ${ }^{20}$

Почетни мотиви (они се подастиру у другом поглављу Арсенијевог житија), нису шире развијени. О домовини јунака говори се сажето. Данило саопштава податак да је Арсеније „рођењем од сремске земље”. ${ }^{21}$ Уводећи мотив родитеља, прибегава апстраховању; потенцира побожност и духовне врлине као суштинско својство предака („,син неких доброверних и побожних родитеља"). ${ }^{22}$ Мотив рођења фактички је запостављен; међутим, наглашена је чињеница да је Арсеније и пре рођења (,,још у материној утроби") био означен Светим Духом. ${ }^{23}$ Детињство и рана младост у делу су овлашно представљени, углавном посредно. Писац наглашава да је од своје младости „био спремљен као непорочан дар Богу” и да се није предао ни ка једној слави или светској сујети. ${ }^{24}$ На идејном али и на фразеолошком плану опажа се блискост са Доментијаном (на сродан начин тај писац утемељује представу о Светом Сави).

Данило одмах затим прибегава приповедном заокрету. Почиње да говори о преокрету који је наступио у јунаковој души, када је богоразумна светлост засијала у његовом срцу. ${ }^{25}$ Он је умним очима спознао пролазност овога света и славе и вечност небеског, припремљеног за праведнике који љубе Господа. ${ }^{26}$ Након тога смислено се побринуо за своју душу, па је на-

\footnotetext{
${ }^{17}$ ДанЖАр, 153.

${ }^{18}$ Исто, 153.

${ }^{19}$ ДомЖСа, 409.

${ }^{20}$ Упореди: ДанЖАр (153): „постаде сродник праведнима...Авраму и Исаку и Јакову” - ДомЖСа (409): „и удостоји се видети превелику светлост, где су велики патријарси и оцеви отаиа, Аврам и Исак и Јаков".

${ }^{21}$ Реч је о оностраном Срему, тј. Мачви.

22 ДанЖАр, 154.

${ }^{23}$ Овде се очигледно остварује потпуни утицај Доментијана.

${ }^{24}$ Доментијан, прибегавајући симболичкој представности, истиче да Растко (истинито семе Божје) од младости своје није прионуо ни ка једној слави од земаљских - ДомЖСа, 9.

${ }^{25}$ Доментијан говори о преображају који је наступио пошто се Растко раљсегао Светим Духом.

${ }^{26}$ Растко је разумео да је овај живот пролазан, метежан и пустошан, и да брзо ишчезава; прозрео је, душевним очима, бесконачни живот и бескрајна добра припремљена праведницима који љубе Бога - ДомЖСа, 9.
} 
пустио „сву красоту овога живота” - дом, богатство, породицу, сроднике и знанце. Подстакнут је био Христовим позивом (цитира се Јеванђеље по Mamejy 19,29 и 10,37). ${ }^{27}$ Данило наглашава да је Арсеније, верујући Господњој речи, и к томе јединоме тврдим умом и нелицемерном љубављу, приступао са смелошћу. ${ }^{28}$ Желео је Њега Јединога да постигне, гонио је један пут којим ће узићи на небеса. Опасавши добрим разумом и чистотом невиности своја бедра, молитвом и постом и духовном љубављу... сам је себе учинио невестом Христовом. ${ }^{29}$ Представљајући преображај Арсенијев и његове подстицаје да се замонаши, Данило се, како се види, значајно ослонио на Доментијана.

Изнова се враћајући на Арсенијеве побуде да напусти световни живот, Данило наглашава да је он од младости заволео монашки живот, јер је горео Светим Духом и увек се молио Богу да буде удостојен такве жеље свога срца. ${ }^{30}$ Одмах се говори о монашењу јунака (није саопштен податак о томе где се оно збило). Затим писац почиње да говори о Арсенијевом подвизавању (,и у том се поче подвизавати на превелику врлину”). ${ }^{31}$ Данило заправо рачуна на то да је његовим читаоцима/слушаоцима позната повест о Арсенијевом монашењу. ${ }^{32}$ Говорећи о самом монашењу, Данило никако није могао да се ослони на Доментијана. Растко је одбегао у Св. Гору и тамо се, тајно, замонашио, преваривши потеру. Арсеније се, по свој прилици, замонашио у неком њему оближњем манастиру. Довршивши приповедање о монашењу, Данило прибегава микро-похвали. Ту се заправо даје каталог Арсенијевих врлина. Интересантно је да ту није реч само о монашким и уопште хришћанским врлинама, већ и о јунаковим заслугама: „постаде светао управљањем, не стекавши обичај никакве преваре ни охолости". ${ }^{33}$ Истичући да сва добра и савете Арсенијеве ни писање ни реч (усмена) не могу довољно исказати, Данило се правда што похвала није шира и обухватнија. ${ }^{34}$

${ }^{27}$ ДанЖАр, 154. И Доментијан као подстицај наводи Христове речи, он према Мт 10,37 и Лк 14,27.

${ }^{28}$ Код Доментијана јавља се сродно место: „И к юему светлим умом погледајући, $u$ дотичући Га се душевним рукама, вапијаше”- ДомЖСа, 15.

${ }^{29}$ Код Доментијана слично (мада не и истоветно): „И наоружавщи се Светим Духом, и богоразумьем и девством чистим бедра своја опасавщи и великом уздржљивошћу, као светилник који гори Христу, сам себе спреми чистом молитвом и духовном љубављу" - ДомЖСа, 9. Овај писац, за разлику од Данила, тежи симболизацији.

${ }^{30}$ Овде се Данило значајније но раније, ослања на Доментијана; упореди: Данило: гораше Светим Духом-Доментијан: ражегавщи се Светим Духом.

${ }^{31}$ ДанЖАр, 155.

${ }^{32}$ Он каже, при крају другог поглавља: „Јер чусте за ґега, христољупии, како остави род телесних отаца и како би позван у небесни свет” - ДанЖАр, 155.

${ }^{33}$ ДанЖАр, 155.

${ }^{34}$ Исто. 
Од трећег поглавља интензивније се изграђује јунаков монашки лик. Арсеније тражи духовног оца и проналази га у Светом Сави, који је у то време српски архиепископ и столује у Жичи. Ово поглавље започиње краћом похвалом, у којој се истичу Савин значај и заслуге: „преосвећени први архиепископ српској земљи”; „по заповести небесног Оца, управљао божаствена предања законским уставима, што је утврђено светим апостолима и богоносним оцима" и др. ${ }^{35}$ Посебно је акцентирана Савина заслуга за објављивање праве и савршене вере у његовом отачаству (реч је о Синодику Православља). Наглашавајући у похвали Савину улогу у крштавању народа, Данило прибегава широј слици; остварује и снажан контраст: светлост - тама: ,jер бањом божаственога крштења окропи народе своје, који су некада живели у мраку таме греховне, ове обновивши вером, учини их синовима светлости, објављујући им опроштај грехова". ${ }^{36}$ Уводећи похвалу Данило фактички сигнализира да жели да у свом делу шире и темељније изгради лик Светог Саве.

Затим се писац посвећује приказивању Арсенијевих побуда да оде код Светог Саве и затражи да га он прими као свог ученика. ${ }^{37}$ Интересовање јунака за Светог Саву, како је то у житију предочено, подстакнуто је сазнањима до којих је дошао у својој средини, слушајући оне који су о архиепископу причали. Чуо је о дивном Савином животу, како Божјом силом проповеда покајање, уводи човекољубље, учи мудрости, сећа се оних који долазе. Арсеније се, сазнавши све ово, испунио неисказаном радошћу и жељом истините љубави. Одмах је („не каснивши ни мало”) похитао ка Преосвећеном кир Сави, који је тада боравио „у рукотвореној својој архиепископији", ${ }^{38}$ Данилов књижевно-уметнички поступак, када је реч о увођењу лика Светог Саве је занимљив. Он најпре, са своје тачке гледишта (из удаљене временске перспективе) даје оцену о Сави; она је генерализована и обухвата најзначајније области његовог ангажовања и заслуге. Потом са становишта јунака, који је савременик, представља Савино деловање. Арсенијево интересовање ограничава се на оно што је за њега, у датом тренутку, од значаја. Светог Саву у првом реду види као изванредног наставника и духовника. Осим тога, он генерализује и рефлектује сазнања која о Сави има његово (Арсенијево) окружење.

Приповедање се потом интензивира. Запостављајући мотив пута (јунак хита), Данило одмах приказује Арсенијев долазак у Жичу. У настојању да што пре дође до Светог Саве, проналази једног монаха и умоли га да о њему извести Преосвећенога; журно даје информације о себи и разлозима због којих је дошао у манастир. Са посебном пажњом Данило

\footnotetext{
${ }^{35}$ Исто.

${ }^{36}$ Исто.

${ }^{37}$ Исто

${ }^{38}$ Исто.
} 
приказује Арсенијев сусрет са Савом. ${ }^{39}$ Извештен о доласку монаха, Сава заповеди да га доведу к њему. Имајући обилну благодат Светог Духа, Сава осмотри Арсенија својим прозорљивим очима; одмах сагледа све његове способности и добре навике. Одмах му „падне на срце” богоугодна мисао - да с љубављу прими Арсенија и да га „доброразумним речима својих поука" поучи, на темељима сопственог искуства, да се подвизава, и тако стекне (,уграби") небеско царство. ${ }^{40}$

Током представљања Савиног реаговања на Арсенијев долазак, писац истиче или пак овлашно назначава поједина Савина значајна својства и особине: Сава поседује дар прозорљивости, добронамерно прихвата онога за кога процени да је вредан труда, брзо доноси одлуке. У овом моменту Данило не цитира већ парафразира Савине речи. Уочљива је, међутим, његова тежња да опонаша аутентични Савин начин изражавања и говор. У Савином Карејском типику, монашки пут (подвизавање) назива се „уским и тужним путем". ${ }^{41}$ Ову перифразу у идентичној функцији користи и Данило (,„оучи га да уским и тужним путем иде у животу овога века”) када говори о Савиној богоугодној помисли да прими Арсенија за свога ученика. ${ }^{42}$ Чест је код Светог Саве контраст: „живот овога века” - „бесконачни живот”. Данило семантизам јунаковог говора обогаћује уводећи синонимске исказе: „вечна обитељ” - „бесконачни живот” - „царство небесно”.

У поменутој сцени тежиште је на приказивању Савиних особина које га чине искусним духовником; у исти мах он се афирмише као човек изванредних квалитета: одлучно прима незнанца, чим сагледа његове вредности; спреман је да своје подвижничко искуство пренесе на будућег ученика и да му у срце усади своју мудрост.

Карактеристично је да од момента када се Сава нађе у улози духовног оца Арсенијевог, он долази у први план. Арсеније ће задуго остати у другом плану. Оваква ситуација умногоме погодује истицању Савиних особина; омогућава увођење разноврсних видова управног говора.

Развијајући сцену, Данило прибегава дијалогу. Сава је у позицији старешине манастира Жиче. Он поставља уобичајено за дату ситуацију питање. Интересује га из кога краја потиче Арсеније, са којом намером долази у манастир. Арсенијев говор је шири; овде су нужно садржане тражене информације. ${ }^{43}$ Он се са поштовањем обраћа Сави; његове речи добро осликавају његово тренутно стање и жељу да буде примљен; очигледно

\footnotetext{
${ }^{39}$ ДанЖАр, 156.

${ }^{40}$ Исто.

${ }^{41}$ Свети Сава, Карејски типик, у: Свети Сава, Сабрани списи. Приредио Д. Богдановић, Просвета-СКЗ, Београд, 1986; типик је на стр. 37-40, место на које се позивамо на стр. 37.

42 ДанЖАр, 156.

${ }^{43}$ Исто.
} 
рачуна на то да је архиепископ о свему већ извештен, па се усредсређује на најзначајније. Акцентира оно што би Саву могло подстаћи да га прими у манастир. Казује како је чуо за добра дела његове светлости, за то да прима свакога ко долази к њему, да свима даје довољно богоразумне поуке. Писац не назначава како су Арсенијеве речи деловале на Саву. Будући да одмах говори о томе да се архиепископ одлучио да прими Арсенија, посредно ставља до знања да су Арсенијеве речи биле делотворне. Сава је свакако био задовољан објашњењима и сазнањем да Арсеније у њему види искусног духовника, спремног да своје свеколико знање пренесе почетнику у монаштву. Међутим, треба се подсетити Данилове информације да је Сава, чим је угледао Арсенија, дакле и пре овог разговора, донео одлуку да постане духовни отац Арсенију и да га прими у манастир. Стога Арсенијеве речи изговорене овом приликом, не могу имати судбински значај. Дијалог који је уведен очигледно има другу функцију: да прикаже успостављање односа: духовни отац - духовно чедо.

Даље казивање у житију одликује одређени динамизам. Примивши Арсенија, Сава га упућује да ради у манастиру са братијом, што му заповеде. Жели да он постане искусан у сваком раду, да би га потом уздигао на виши чин. Од тог тренутка заправо започиње Арсенијево подвизавање под Савиним руководством. Тај период темпорално је рашчлањен. Карактеристично је да Арсеније непрекидно тежи све строжијим видовима подвизавања и да се успиње на ,лествици врлина”. Домете процењује Сава, који доноси одлуке о евентуалном напредовању у положају. Арсеније иде „уским и тужним путем”, стичући одређене, све важније функције. Савина љубав према Арсенију, како то наглашава Данило, непрекидно расте.

Лирским тоном и посредством поетских (изграђују се око симбола извор и срие), представљено је Савино континуирано поучавање Арсенија; у исти мах истакнут је и значај тих поука: „Дејством Пресветога Духа узведе га на пресветлу светлост божанственог разума, и као од медоточнога извора поука и речи својих, напоји душевне бразде срца његова, да се у њима он поучавао дан и ноћ." ${ }^{44}$ Писац се сасвим усредсређује на Савину улогу духовног оца. Исказана је велика похвала његовом беседничком дару и мудрости. Данило наглашава како је Арсеније прво примио смерну мудрост и послушање. Према пишчевој оцени, то је прво добро које је примио од Саве.

Мотив подвизавања шире је утемељен. Запажа се пишчева тежња да назначи и конкретне појединости. Несумњив је снажан утицај Доментијана; преузети модел се дограђује, да би се остварио потребни степен аутентичности: „и у сваком делу манастирске работе успевао је више од свих, и у молитвама беше напредан, тако да никада није погрешио устав

${ }^{44}$ Исто, 156. 
и исправљање црквено дању и ноћу, или да је због каквог узрока када закаснио”. ${ }^{45}$ На Доментијана највише подсећа Данилова реченица: „и тако живећи међу братијом... једно је гледао, чекајући да прими помоћ од Вишњега."

И у тексту који следи истиче се чињеница да је Сава узор Арсенију. Он посматра подвиге и неисказане трудове свога доброг учитеља кир Саве, ревнујући његовим делима. Остаје у Жичи, са великим мучањем и кротошћу. Арсенију је узор Свети Сава, а он сам се угледао на прве свете мужеве, осниваче монаштва; о томе сведочи Доментијан у своме Житију: „хотећи најпре да своју душу од страсти ослободи, подобећи се животу првих светих мужева, који претекоше овај живот у мукама и жалостима многим; други од њих својом крвљу купише вечни живот и настанише се у небеским селима, пример показавши онима који желе да траже вечни живот." $" 47$

Данило се у делу дотиче и незаобилазне теме искушења. Према његовим речима, због строгог поста и лишавања сна (,по мери је јео хлеб и по мери пио воду, и то само у одређено време”; „никада ноћу није дао у сласт сна своме телу нити покоја"), никада није обратио ум на нападе бесова. ${ }^{48}$ Овај сегмент текста необично је значајан, јер указује на пишчеву снажну интенцију да Арсенија знатније приближи Светом Сави. Наиме, и Светог Саву и бесови толико не искушаваху, због његовог строгог подвизавања и рада у манастиру, како Доментијан указује. ${ }^{49}$

Приказујући Арсенијеву бригу за сопствену душу, Данило уводи унутрашњи монолог. ${ }^{50}$ У тежњи да стекне небеско царство, како то формулише Данило - да се ,јави за царство небеско”, као истинити житељ и вечни грађанин Вишњег Јерусалима, Арсеније се обраћа својој души (апострофирана је као „убога” и „грехољубива”). Подстиче је на подвизавање, не би ли угодила Господу. Упечатљиво и врло емотивно својој души предочава смртност (,,јер знаш да се твој век у овом сујетном животу свршава”) и будуће, вечне, муке. Пита је због чега очајава. Уведени монолог осим што је занимљиво структуриран и емотивно интониран, поседује још једну карактеристику. Поједини искази сродни су исказима који се сусрећу у монологу краљице Јелене (и она се обраћа својој души, подстичући је да оплакује себе, због бројних грехова). ${ }^{51}$

\footnotetext{
${ }^{45}$ Исто.

${ }^{46}$ Исто.

47 ДомЖСА, 77.

${ }^{48}$ ДанЖАр, 156.

49 ДомЖСа, 77.

${ }^{50}$ ДанЖАр, 157.

${ }^{51}$ Данило Други, Житије краљице Јелене, у: Данило Други, Животи краљева и архиепископа српских. Службе, 79-107, на стр. 83.
} 
При крају поглавља Данило, похваљујући Арсенија, истиче да се он, ревнујући животу светитеља сваким делом, подвигом прочуо, јер је надмашио све друге монахе у Жичи". ${ }^{2}$ Мада то изричито не спомиње, писац несумњиво сматра Светог Саву заслужним за овакав јунаков напредак.

У четвртом поглављу приказано је даље Савино старање о духовном напредовању Арсенијевом. Посматрајући колике су благодати и подвизи Арсенијеви, архиепископ се веселио због тога. Истовремено, молио се Богу да јаче утврди ум Арсенијев. Са тим циљем чинио му је разна искушења (овде су представљена нека од њих: Сава је заповедио да се Арсенију уместо вина током обеда даје сирће или пак лоше спремљено јело, желећи да установи да ли ће узревновати, тј. подвизавати се на боље, или ће узнегодовати). Показало се да Арсеније не само да није негодовао, већ је све што му је давано са благодарношћу примао. Желео је да још више буде искушаван, па је тражио ,јело оштро или тврђе”, како се његово грло никада не би насладило. ${ }^{53}$

Данило, исказујући изнова сопствену блискост са Светим Савом („овај господин мој кир Сава”), напомиње да је Сава, сагледавши каква се неисказана благодат догађа на Арсенију, њега узео у своју ћелију, како би Арсеније стајао пред њим и навикао се већем савршенству, подвизавајући се добрим подвигом. ${ }^{54}$

При крају поглавља сусреће се похвала Арсенију; започиње истицањем чињенице да је Арсеније истинити, разумни ученик учитеља свих Христа и Савин ученик. Христа је, наглашава писац, за учитеља стекао послушавши његове речи у раној младости (позив да се све напусти и за Њим крене). Савин ученик постао је пошто је уловљен од њега (Саве). Ефекат Савиног поучавања сликовито је представљен: Арсеније је слатким поукама цветао као добромирисним и многоразличним цветовима, желећи да се након Саве јави као други учитељ и наставник свога отачаства. ${ }^{55}$ Када говори о Савиној улози и његовом утицају на Арсенија, Данило то чини на лирски начин, прибегавајући поетско-симболичким сликама. Одабрана симболика никако није случајна, већ је у функцији постизања пожељне асоцијативности. Сам Сава је налик на Христа, који је учитељ (сам је, како то Доментијан приказује, био уловљен од Христа и напустио је световни живот; код овога писца симбол лов има и шири семантизам). Представљајући дејство Савиних поука, Данило у средиште поставља симбол ивет, који припада регистру биљних симбола. Око њега изграђује ширу и симболичку слику, посредством које поспешује представу о Арсенијевим врлинама. У похвали је акцентирана чињеница да је Арсеније све

\footnotetext{
${ }^{52}$ ДанЖАр, 157.

${ }^{53}$ Исто, 157.

${ }^{54}$ Исто, 158.

${ }^{55}$ Исто.
} 
чинио што је видео да чини Свети Сава, који се „од почетка” трудио више од свих. Овде је, готово узгредно, зачета и похвала Савином подвигу. Даље се истиче Божје старање о Арсенију - шаље му своју светлост и истину, приводећи га ка таквом уздању, којим се траже вишње ствари и небеска слава - да ревнује животу преподобних и праведних. Након похвале следи опис Арсенијевог подвизавања, које је строже него у претходном раздобљу (подвизава се изнад снаге, строго пости, показује велику ревност у поштовању свих устава ноћног појања). ${ }^{56}$ Да и на овом месту Данило умногоме обликује Арсенијев лик према идеалном прототипу - Светом Сави, упућују поједине вредносне ознаке и судови. Када констатује да је он ревновао животу преподобних и праведних, свакако је подстакнут сродном изјавом о Светом Сави, коју је дао Доментијан.

Пратећи непрекидно Арсенијево напредовање, Данило у петом поглављу говори о томе да је Сава, спознавши да је Арсеније „достојан да разумно и самислено послужи и у такву делу”, њему поверио да „предржи свету и божаствену цркву". ${ }^{57}$ Са посебном пажњом потом је приказано Савино настојање да Арсенија упути у дужност (позвао га је к себи, доброразумним речима „објавио му је све црквене уставе”, итд.). Сава из своје руке предаје Арсенију црквене кључеве и даје му савршени благослов. Савине речи су цитиране; овде су сусрећу и поуке. Говор је пажљиво профилисан, карактерише га одређена сликовност (,,тежину сна отреси од себе”, „,убистри свој ум на покајање”, итд.). ${ }^{58}$ Архиепископ говори смирено али и веома мудро. На овом месту исказује се као искусни духовни отац; испољава присност и бригу за духовно чедо. Наликује на стварног Саву, каквим га откривају поједине странице његовог Хиландарског типика.

Паралелним планом приказан је Арсенијев труд. Мада уведен у значајну дужност, никако није попустио у подвигу, већ се ,још на веће подвизавао". ${ }^{99}$ Пишчева назнака да је у Арсенија Дух Господњи удахнуо и да му је учинио све могуће, важна је јер омогућава да се доведе у везу са Савом (Доментијан говори о учинку Светога Духа на Саву). У овом раздобљу, како је у житију представљено, јунак нарочито испољава своју мудрост и разум. Брине се за цркву „као за своју душу”.

Свети Сава, мада је у потпуности упутио Арсенија у дужност, није напустио бригу о њему. Данило износи необично важну појединост: apхиепископ је Арсенија непрекидно надзирао са своје катихуменије. ${ }^{60}$

У истом поглављу житија приказује се Арсенијев избор за еклисијарха „велике и саборне цркве архиепископије”, тј. Жиче. О томе је одлуку

\footnotetext{
${ }^{56}$ ДанЖАр, 158.

${ }^{57}$ Исто.

${ }^{58}$ Исто, 159.

${ }^{59}$ Исто.

${ }^{60}$ Исто, 160.
} 
донео Свети Сава. Арсеније, у складу са успостављеном праксом, сада се још више подвизава. Многа његова добра дела привлаче пажњу српског краља и велике властеле; почињу да испољавају љубав према њему. И сам његов духовни учитељ, Свети Сава, почео је да га веома воли, чинећи му многе части.

Суштински заокрет у приповедању наступа са шестим поглављем. ${ }^{61}$ Ту се говори о Савиној намери да оде на ходочашће у Свете Земље и његовој одлуци да пре путовања напусти архиепископски трон и на своје место постави другога. Сава је много размишљао о томе кога да одабере (Данилове су речи: „у уму своме тражио је таквога мужа”) и одлучио се за Арсенија, „кога беше научио из својих уста свакој доброј навици” и кога му је Бог објавио као достојног. ${ }^{62}$ У седмом поглављу представљена је хиротонија, узвођење Арсенија на архиепископски престо. ${ }^{63}$ У византијским словенским па и у српским житијима црквених поглавара централно место заузима опис њиховог избора у тај чин. Временом успостављена су нека општа места. Јунаку се више пута нуди црквени чин и он га непрестано одбија, сматрајући себе недостојним. Обично је сам цар иницијатор хиротонисања, али се у тој улози могу појавити и грађани и др. Јунак најчешће два пута одбија да буде изабран а затим се њему самом или иницијатору избора открива да Бог жели да буде изабран. Јунак најзад даје свој пристанак. Следе припреме за спровођење самог избора. Опис процедуре обично није опсежније приказан. У Доментијановом Житију Светог Саве, на које се Данило највише ослања, опис Савиног хиротонисања за српског архиепископа представља централни мотив. Опис хиротонисања - предисторија, сама процедура, итд., доста је дуг. На кратку и информативну експозицију о томе како је Сава отишао на исток код византијског цара, кир Теодора Ласкара, надовезује се веома упечатљив дијалог између цара и Саве. Увођењем дијалошке форме Доментијан надилази успорен дескриптивни ритам и речима самих јунака осмишљава њихове намере и остварује портрете. Ово поглавље има карактеристичну, веома занимљиву структуру и сложена значењска језгра. Дијалог смењује приповедање о самом чину хиротонисања. У истом поглављу писац даје текст повеље (томоса), користи се монологом, да би на крају увећао експресивност свога приповедања лирском изражајношћу. Тај део прераста у похвалу чиме се, у жанровском смислу, обогаћује овај и иначе у том погледу богати део житија. ${ }^{64}$

Данилов опис хиротоније и у погледу опсежности и у погледу књижевно-уметничке слојевитости разликује се од Доментијановог. Околности

\footnotetext{
${ }^{61}$ Шесто поглавље заузима простор на страницама 161-163.

62 ДанЖАр, 161.

${ }^{63}$ Седмо поглавље је на стр. 163-164.

${ }^{64}$ Опис Савиног избора за архиепископа: ДомЖСа, стр. 193-203 (непарне).
} 
избора и процедура су другачији (Арсенијев избор одвија се у Србији, пред црквеним сабором). Данило је свестан значаја који догађај има не само за главног јунака већ и за српску средину. Преузима традиционална решења али их и стваралачки преосмишљава. Главну улогу има Свети Сава, који је иницијатор и фактички реализатор читавог избора.

Истичући Савину личност у први план на почетку шестог поглавља, Данило прибегава краћој похвали. ${ }^{65}$ Ту велича и прославља Савине врлине; указује да је Сава у телу имао живот бестелесних (анђела), да је управљао реч истине. Глорификујући га, користи за њега квалификатив: проповедник побожности. Писац затим говори о Савиној жељи да види света места и ,добре животе оних који работају Господу”. ${ }^{66}$ Радостан због предстојећег пута, старао се да пронађе достојног наследника и да њему препусти свој архиепископски трон. Према Даниловим речима, Сава је много размишљао, трагајући за подобном личношћу. Није нашао никога другога до Арсенија „кога беше научио из својих уста свакој доброј навици”. ${ }^{67}$ Након донете одлуке, Сава је позвао Арсенија к себи и „објавио му је своју мисао". Његов говор је емотивно интониран; речи су пажљиво одабране. ${ }^{68}$ Апострофа (сусреће се два пута) открива присност и Савину велику љубав према ученику: „чедо моје вазљубљено у Господу, Арсеније”, „вазљубљени души мојој”. Говор започиње указивањем на важност онога што ће бити саопштено. Ефектно је прибегнуто коришћењу стиха из Прича Соломонових $(5,1)$ : „приклони ухо твоје и разумно чуј речи моје, јер нису на штету души твојој”. У истом, лирском тоналитету, је и Савина поука упућена Арсенију - да сачува речи у својим душевним недрима и да оне буду непрестано у његовој памети, како се не би устрашио ђавољег искушења. ${ }^{69}$ Током обраћања Сави говори и о свом односу према Арсенију, од момента његовог доласка у Жичу; наглашава да љубав срдачне вере његове према Арсенију никако није слабила. Свети Сава се осврће и на сопствени уложени труд и на резултате постигнуте у поучавању (учио је Арсенија сваком добром исправљењу; Арсеније се добро навикао и у свему може се угодан јавити Господу). Довршавајући говор, Сава указује на своју намеру да отпутује и да уместо себе остави Арсенија, да буде управљач свете вере, чувар и пастир умнога стада христоименитих оваца.

У карактеризацији Светог Саве ово житијно место има велики значај. Овде се формално довршава његова улога Арсенијевог духовника. У овом моменту он је на врхунцу своје духовне снаге и мудрости. Врло концизно али необично логично и складно износи своја виђења и намере. Импонује

\footnotetext{
${ }^{65}$ ДанЖАр, 161.

${ }^{66}$ Исто.

${ }^{67}$ Исто.

${ }^{68}$ Савино обраћање Арсенију је на стр. 161.

${ }^{69}$ ДанЖАр, 161.
} 
његов духовни мир. Треба одати признање писцу за представу Светог Саве каква је овде пружена. Она се несумњиво утемељује на сазнањима која је о Сави стекао читајући његове списе.

Потом је у делу приказано дејство Савиних речи на Арсенија. Он је веома уплашен (,обузе га велики трепет”), помишља да је реч о неком искушењу. ${ }^{70}$ Најпре не уме ништа да одговори и дуго ћути; најзад, пренувши се као из сна, изјављује да је чуо речи које су тешко подношљиве његовом уму, јер изазивају недоумицу. Писац на овом месту снажно развија психолошки план, да би мотивисао поступке свога јунака. Пошто Сава потврди да је све што је изрекао истина, Арсеније моли Саву да га не бира, јер је грешан и недостојан. Не желећи да се разлучи од свога доброг хранитеља и учитеља, он помишља да са Савом крене на пут. Свој пристанак да буде постављен за црквеног поглавара даје тек пошто га Сава извести да га је њему Бог показао као достојног да постане архиепископ.

Данило овде несумњиво остаје доследан установљеном моделу (јунак најпре одбија положај а потом га прихвати). Дијалог који се одвија између Светог Саве и Арсенија изванредно осликава атмосферу и доприноси карактеризацији оба лика. Док код Доментијана влада свечаност, присутна је етикеција, код Данила се сусреће непосредност. Сава говори разложно, смирено, испољавајући међутим снажну љубав према Арсенију. Арсеније, пак, врло је узнемирен и уплашен; он не жели да се одвоји од Саве. Искрено сматра да није достојан високе дужности, коју је изванредно обављао Свети Сава.

Након приказивања Савиног разговора са Арсенијем, Данило се усредсређује на приказивање сабора. ${ }^{71}$ Сава ту говори о свом одласку и о наследнику кога оставља. Говор пропраћа горки плач присутних; они са великом жалошћу наричу и вичу; обраћају се Сави - добром и благом пастиру, који је положио своју душу за њих, сам собом показао истинити пример врлина, неослабно хранио беседама и духовним речима душе оних, који су са вером прилазили к њему, који је све водио на пут живота. Питају се ко се може наћи њима уместо њега, такав као што је он, и моле га да не оставља њих, сироте.

Ово место наликује на плач за Немањом из оквира Савиног Житија Светог Симеона. ${ }^{72}$ Као и у том делу, и овде је кроз форму плача исказана општа похвала јунаку.

Данило потом говори о (неуспелом) покушају краља (он помиње Радослава а заправо је реч о Владиславу) да одговори Саву од пута. Одмах потом прибегава похвали. Говорећи о Сави најпре у симболичкој равни,

\footnotetext{
${ }^{70}$ Исто, 162.

${ }^{71}$ Исто, 162-163.

${ }^{72}$ Свети Сава, Житије Светога Симеона, у: Свети Сава, Сабрани списи, 101.
} 
истиче да је праведно семе, и да је од младости уловљен од Бога. Његову изузетност наглашава тиме што каже да је Бога свагда гледао пред својим очима. ${ }^{73}$

У седмом поглављу представљено је Арсенијево освећење за архиепископа. ${ }^{74}$ Данило приказује саму процедуру, нарочито истичући Савину улогу. Пошто је Арсенија својом руком поставио на трон и приредио славље (присутан је и српски краљ), Сава поучава Арсенија о божаственим правилима законскога предања и о душевној користи. Дирљиве су речи које Сава том приликом изговара - да не зна да ли ће га Арсеније поново, пре смрти, угледати у телу.

У посебном поглављу (осмо) говори се о Савиним непосредним припремама за одлазак, одласку у Стари Град (Будву). Шире, и са низом појединости, представљено је укрцавање у лађу и жалост народа који га испраћа. ${ }^{75}$ Према Даниловим речима, народ се, горко жалећи због растанка са добрим учитељем и наставником, окупио око Саве. Видевши да му досађују, изненада и брзо ушао је у лађу и заповедио да се она мало навезе на пучину. У овом тренутку Данило Саву упоређује са Христом, коме су, својевремено, „народи досађивали”; ушао је у лађу и заповедио да се одвезе; потом је сео и из лађе учио људе. Сава је, стојећи у лађи, поучавао своја чеда, дајући им мир. Са лађе послао је благослов архиепископу Арсенију, благословио је сву земљу свога отачаства и помолио се своме вођи Христу за њено утврђење. Потом је почео да плови морском пучином, Господом крмањен.

Архиепископ Данило Други, коме је узор у монаштву био Свети Сава, у свом делу посвећеном Арсенију Сремцу о Сави је писао са топлином и љубављу. Прибегао је разноврсним средствима директне портретизације (управни говор, поуке) и индиректне (похвале, похвална места, паралеле, сведочења и др.), у настојању да што рељефније изгради Савин лик. Пажљиво одабирајући сцене и оснажујући спону: Арсеније - Свети Сава, Данило је остварио могућност да шире, темељније и уметнички експресивније говори о Светом Сави.

\footnotetext{
${ }^{73}$ ДанЖАр, 163.

${ }^{74}$ Исто, 163-164.

${ }^{75}$ Исто, 165.
} 